\title{
Spiroplasma atrichopogonis sp. nov., from a ceratopogonid biting midge
}

Correspondence

Gail E. Gasparich

ggasparich@towson.edu

\author{
R. Thomas Koerber, ${ }^{1}$ Gail E. Gasparich, ${ }^{1}$ Mark F. Frana ${ }^{2}$ \\ and William L. Grogan Jr² \\ ${ }^{1}$ Department of Biological Sciences, Towson University, Towson, MD 21252, USA \\ ${ }^{2}$ Department of Biological Sciences, Salisbury University, Salisbury, MD 21801, USA
}

\begin{abstract}
Spiroplasma sp. strain GNAT3597 ${ }^{\top}$ was isolated from the biting midge genus Atrichopogon (Diptera: Ceratopogonidae). It was serologically distinct from other Spiroplasma species, groups or subgroups. Dark-field microscopy of the cells revealed the classical helical shape and subsequent transmission electron microscopy revealed cells surrounded by only a cell membrane (i.e. lacking a cell wall). Growth of strain GNAT3597 ${ }^{\top}$ occurred in M1D medium at $30^{\circ} \mathrm{C}$. Strain GNAT3597 ${ }^{\top}$ catabolized both glucose and arginine, but did not hydrolyse urea. The DNA G $+C$ content of strain GNAT3597 ${ }^{\top}$ was $29 \pm 1$ mol\%. Only one strain, SMCA ${ }^{\top}$ (Spiroplasma mirum), is serologically related to strain GNAT3597 ${ }^{\top}$, although the relationship is weak (positive reaction to only a $1: 80$ dilution). It is therefore proposed that strain GNAT3597 $^{\top}$ (=ATCC BAA $-520^{\top}=$ NBRC $100390^{\top}$ ) represents a novel species, Spiroplasma atrichopogonis sp. nov. (class Mollicutes: order Entomoplasmatales: family Spiroplasmataceae).
\end{abstract}

\section{INTRODUCTION}

Spiroplasmas are host-specific microbes of the class Mollicutes (Tully et al., 1993, 1987; Williamson et al., 1989). They most commonly reside in the lumen of the gut of insects as commensal organisms, but can also invade into the haemocoel and/or move to different organs (e.g. salivary glands and ovaries) (Hackett \& Clark, 1989). A few spiroplasmas are vectored to the sieve tubes of plants by their insect hosts causing detrimental effects to the plant's health (e.g. citrus stubborn disease and corn stunt disease). Since the first spiroplasma was cultivated in 1973 (Saglio et al., 1973), more than 1000 spiroplasma isolates have been obtained (Hackett, 1990; Hackett \& Clark, 1989; French et al., 1990). Of these isolates, several have been shown to be pathogens to their insect hosts, whereas others are commensals (Hackett \& Clark, 1989; Clark, 1982; Clark et al., 1984). In the order Diptera, spiroplasmas have been isolated from fruit flies (Drosophilidae) (Williamson et al., 1999), several genera of mosquitoes (Culicidae) (Chastel \& Humphery-Smith, 1991), a hover fly (Syrphidae) (Whitcomb et al., 1996), and from several genera of deer and horse flies (Tabanidae) (Whitcomb et al., 1997). The success of isolations from dipteran hosts led to the investigation of biting and predaceous midges (Ceratopogonidae) as spiroplasma hosts.

Strain GNAT3597 ${ }^{\mathrm{T}}$ was isolated from biting midges from Salisbury, MD (Wicomico County), USA. The insects were collected by light trap or by sweeping insect nets on flowers and other vegetation. The isolation and initial cultivation efforts have been described previously (Frana et al., 2001).
Several characteristics are common amongst all spiroplasmas, including the classic spiral/helical shape, lack of a cell wall, glucose fermentation and a growth temperature requirement of about $30^{\circ} \mathrm{C}$ (Tully \& Whitcomb, 1991). Classification of spiroplasmas provides useful information concerning species relationships. Information obtained from the characterization tests can then be added to a growing database of all species in the genus Spiroplasma.

The classification of spiroplasmas requires several morphological, biochemical and genetic tests as prescribed by the International Committee on Systematic Bacteriology Subcommittee on the Taxonomy of Mollicutes (1995). Cultivation of spiroplasmas can be achieved in various media, with the best growth typically occurring in M1D medium (Whitcomb, 1983). Identification methods for spiroplasmas include simple microscopy, usually under a dark-field microscope to show the classical helical shape, and determination of the lack of a cell wall by transmission electron microscopy. Biochemical, serological and genetic tests $(\mathrm{G}+\mathrm{C}$ content analysis) are also components of the classification of spiroplasmas.

In this report, the results of taxonomic studies of strain GNAT3597 ${ }^{\mathrm{T}}$ that satisfy the requirements for descriptions of species in the class Mollicutes (International Committee on Systematic Bacteriology Subcommittee on the Taxonomy of Mollicutes, 1995) are reported. Results support the designation of strain GNAT3597 ${ }^{\mathrm{T}}$ (= ATCC BAA $-520^{\mathrm{T}}=$ NBRC $100390^{\mathrm{T}}$ ) as the type strain of a novel species, Spiroplasma atrichopogonis sp. nov. 


\section{METHODS}

Isolation and cultivation. Spiroplasmas were isolated from a pooled sample of two species of biting midges, Atrichopogon levis and Atrichopogon geminus, and initially cultured in R2 medium and incubated at $30{ }^{\circ} \mathrm{C}$ (Frana et al., 2001). The culture was subsequently triple-cloned in M1D medium using filtration cloning procedures as described previously (Tully, 1983a) and designated strain GNAT3597 ${ }^{\mathrm{T}}$. Representative strains of previously recognized groups and subgroups, including the type strains of previously recognized species (Williamson et al., 1998), were cultivated for comparative purposes. All spiroplasmas were grown at $30^{\circ} \mathrm{C}$.

Morphological studies. Cells from exponential cultures of strain GNAT3597 ${ }^{\mathrm{T}}$ were examined by dark-field microscopy (magnification $\times 1000$ ) and by the physical colour change of the medium (from red to yellow). For electron microscopy, $20 \mathrm{ml}$ exponential cultures of strain GNAT3597 ${ }^{\mathrm{T}}$ were pelleted and fixed for $2 \mathrm{~h}$ in $3 \%$ glutaraldehyde, post-fixed by a $1 \%$ osmium tetroxide treatment for $3 \mathrm{~h}$, and then dehydrated in acetone and embedded in Spurr's Embedding Medium (Williamson, 1983). Sections were stained with $2 \%$ aqueous uranyl acetate and Reynolds' lead citrate prior to visualization.

Deformation test. Strain GNAT3597 ${ }^{\mathrm{T}}$ was tested serologically against the hyperimmune antisera of 40 different species of spiroplasmas that represent established type strains (Williamson et al., 1998) using the deformation test as described previously (Williamson et al., 1978). Positive reactions were confirmed by the presence of grape-like clusters on the spiroplasma, indicative of a reaction between the cell membrane and the antisera. The presence of normal, helical/spiral-shaped spiroplasmas indicated no reaction to the antiserum (Williamson et al., 1978). Spiroplasma syrphidicola (strain EA-1 ${ }^{\mathrm{T}}$ ) and Spiroplasma citri (strain $\mathrm{R} 8 \mathrm{~A} 2^{\mathrm{T}}$ ) were also tested against their own antiserum as controls. This procedure was performed twice. Antiserum to strain GNAT3597 ${ }^{\mathrm{T}}$ was produced in rabbits as described previously (Williamson et al., 1978). This antiserum was then used in reciprocal deformation tests against strains whose antisera had a positive reaction against strain GNAT3597 ${ }^{\mathrm{T}}$.

Metabolism inhibition test. Strain GNAT $3597^{\mathrm{T}}$ was serologically tested against the hyperimmune antisera of the most closely related insect species (Williamson \& Whitcomb, 1983). Colour change, or lack of, was noted to determine if growth was established in each of the microtitre plate wells. This procedure was performed twice.

Biochemical tests. Strain GNAT3597 ${ }^{\mathrm{T}}$ was weaned from M1D medium onto a minimal medium [serum fraction (SF) broth supplemented with $1 \%$ bovine serum fraction (Tully, 1983b)] by sequential passage from $3: 1$ (M1D:SF) to $1: 1$ to $1: 3$ and finally into SF plus $10 \%$ glucose. After weaning, strain GNAT3597 ${ }^{\mathrm{T}}$ was used to inoculate five tubes for biochemical testing as follows: tube 1, SF; tube 2, SF and $10 \%$ glucose; tube 3, SF, $10 \%$ glucose and $21 \%$ arginine; tube $4, \mathrm{SF}$ and $21 \%$ arginine; and tube $5, \mathrm{SF}$ and $1 \%$ urea (Aluotto et al., 1970). Dark-field microscopy, as well as colour change, was used to identify growth of the cultures. For the arginine samples, the colour change was from red to yellow and then back to red. Multiple tests were performed to ensure results and repeatability.

G+C content analysis. Strain GNAT3597 ${ }^{\mathrm{T}}$ was grown in a large culture $(100 \mathrm{ml})$ and DNA was extracted as described previously (Gasparich et al., 1993). The DNA was diluted in $1 \times$ SSC buffer to give a final sodium concentration of $0 \cdot 195 \mathrm{M}$. This sample was used (with a $1 \times$ SSC buffer blank) in a Cary Varian Thermal Spectrophotometer equipped with software to determine the melting temperature and the $\mathrm{G}+\mathrm{C}$ content was determined (Carle et al., 1983). This process was repeated several times; Escherichia coli DNA in $1 \times$ SSC buffer was used as a control to verify the results.

\section{RESULTS AND DISCUSSION}

Characterization of Spiroplasma sp. strain GNAT3597 ${ }^{\mathrm{T}}$ was performed using the designated characterization tests as determined by the International Committee on Systematic Bacteriology Subcommittee on the Taxonomy of Mollicutes (1995).

\section{Cultural and morphological properties}

Strain GNAT3597 ${ }^{\mathrm{T}}$ grew well in M1D medium containing $500 \mathrm{U}$ penicillin $\mathrm{ml}^{-1}$. Exponential-phase cultures of strain GNAT3597 $^{\mathrm{T}}$ in M1D medium examined by dark-field microscopy revealed helical, motile filaments with four to five turns per cell. Transmission electron microscope analysis revealed that cells were filamentous with no evidence of a cell wall (Fig. 1). Cells were about $150 \mathrm{~nm}$ in diameter and were surrounded by a single cytoplasmic membrane.

\section{Serological tests}

Metabolism inhibition and deformation tests indicated that strain GNAT3597 ${ }^{\mathrm{T}}$ was unrelated serologically to representatives of previously established Spiroplasma groups or subgroups. There were no detectable serological reactions of strain GNAT3597 ${ }^{\mathrm{T}}$ with any of the type strain antisera in the metabolism inhibition assays. The serological reactions of strain GNAT3597 ${ }^{\mathrm{T}}$ in the deformation test against strains isolated from related host organisms are summarized in Table 1. There was a slight reaction with strain $\mathrm{SMCA}^{\mathrm{T}}$ up to 160 -fold dilution. A reciprocal deformation test using strain GNAT3597 ${ }^{\mathrm{T}}$ antiserum against the seven strains indicated in Table 1 gave no detectable reaction at 20 -fold dilution. Homologous titres for strains $\mathrm{R} 8 \mathrm{~A} 2^{\mathrm{T}}$, TAAS- 1 and $\mathrm{SMCA}^{\mathrm{T}}$ (controls) were all 2560, which is what has been

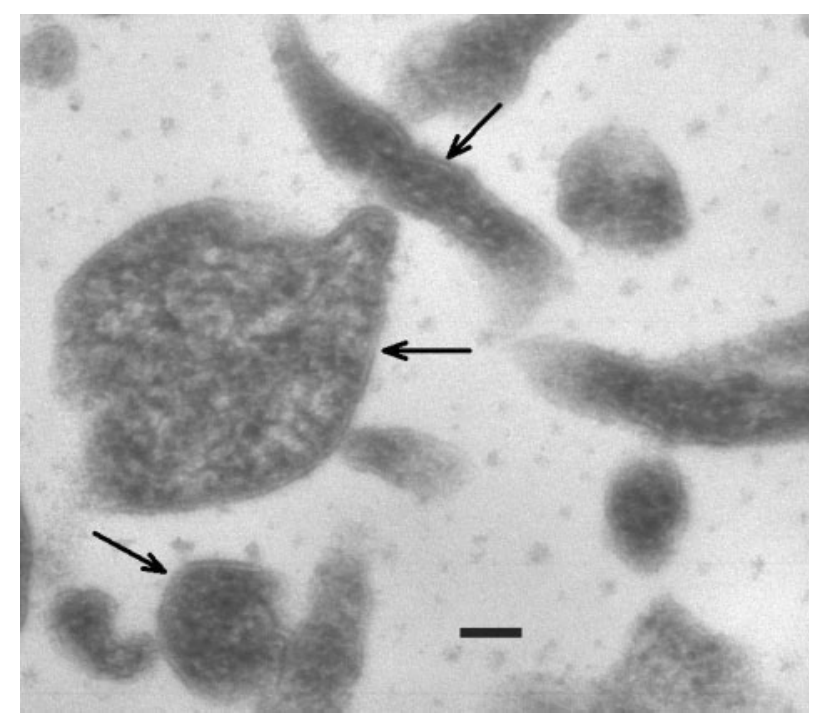

Fig. 1. Transmission electron micrograph of cells of strain GNAT3597 $^{\top}$ (arrows indicate cell membrane). Bar, $0 \cdot 1 \mu \mathrm{m}$. 
Table 1. Serological reactions of strain GNAT3597 ${ }^{\top}$ in the deformation test (DF) against the seven most closely related species

\begin{tabular}{|llc|}
\hline $\begin{array}{l}\text { Antisera Spiroplasma } \\
\text { group and strain }\end{array}$ & $\begin{array}{l}\text { Spiroplasma strain host } \\
\text { organism (order: family) }\end{array}$ & $\begin{array}{r}\text { Titre in } \\
\text { DF test }\end{array}$ \\
\hline V, SMCA $^{\mathrm{T}}$ & Parasitiformes: Ixodidae & 160 \\
VIII-2, DF-1 $^{\mathrm{T}}$ & Diptera: Tabanidae & $<20$ \\
VIII-3, TAAS-1 $^{\mathrm{T}}$ & Diptera: Tabanidae & $<20$ \\
X, AES-1 & Diptera: Culicidae & $<20$ \\
XVI-3, Ar-1357 $^{\mathrm{T}}$ & Diptera: Culicidae & $<20$ \\
XXIII, TG-1 $^{\mathrm{T}}$ & Diptera: Tabanidae & $<20$ \\
XXXII, TABS-2 $^{\mathrm{T}}$ & Diptera: Tabanidae & $<20$ \\
\hline
\end{tabular}

reported previously (Hackett et al., 1996). The homologous titre for strain GNAT3597 ${ }^{\mathrm{T}}$ was also 2560.

\section{Biochemical and biological properties and $\mathbf{G}+\mathbf{C}$ content}

After subsequent weanings into SF and glucose, strain GNAT $3597^{\mathrm{T}}$ was able to grow in media containing glucose, glucose plus arginine and arginine alone, indicating that it is able to ferment glucose with the production of acid and catabolize arginine. No growth was observed in SF plus urea, indicating that urea is not hydrolysed. Strain GNAT3597 passed readily through membrane filters with pore sizes of 450 and $220 \mathrm{~nm}$. A $100 \mathrm{~nm}$ pore size membrane filtrate was free of viable cells.

The base composition ( $\mathrm{G}+\mathrm{C}$ content) of the DNA of strain GNAT3597 ${ }^{\mathrm{T}}$ was $28 \cdot 79,28.90$ and $28.79 \mathrm{~mol} \%$ (average $28 \cdot 8 \pm 1 \mathrm{~mol} \%)$.

\section{Description of Spiroplasma atrichopogonis sp. nov.}

Spiroplasma atrichopogonis [a.tri.cho.po.go' nis. N.L. gen. n. atrichopogonis of Atrichopogon, systematic genus name of a biting midge (Diptera: Ceratopogonidae)].

Cells are filamentous, helical and motile and about $150 \mathrm{~nm}$ in diameter. They freely pass through filters with 450 and $220 \mathrm{~nm}$ pores, but do not pass through filters with $100 \mathrm{~nm}$ pores. The cells lack true cell walls. Chemo-organotrophic. Acid is produced from glucose and arginine is catabolized. Does not utilize urea. Serologically distinct from previously established Spiroplasma species, groups and subgroups.

The type strain is GNAT3597 ${ }^{\mathrm{T}}$ (=ATCC BAA $-520^{\mathrm{T}}=$ NBRC $100390^{\mathrm{T}}$ ), isolated from a pooled sample of two nearly identical species of biting midges (Atrichopogon geminus and Atrichopogon levis); the entire insects were ground up in media prior to incubation. Pathogenicity for these flies is not known. The $\mathrm{G}+\mathrm{C}$ content of the DNA of the type strain is $28 \cdot 8 \pm 1 \mathrm{~mol} \%$, as determined by the melting-temperature method.

\section{ACKNOWLEDGEMENTS}

This work was supported in part by the NSF REU grant number 9732442 and by the Towson University College of Science and Mathematics Committee on Undergraduate Research. We also gratefully acknowledge support from the Henson School of Science \& Technology and the Department of Biological Sciences at Salisbury University.

\section{REFERENCES}

Aluotto, B. B., Wittler, R. G., Williams, C. O. \& Faber, J. E. (1970). Standardized bacteriologic techniques for the characterization of Mycoplasma species. Int J Syst Bacteriol 20, 35-58.

Carle, P., Saillard, C. \& Bové, J. M. (1983). Determination of guanine plus cytosine content of DNA. Methods Mycoplasmol 1, 301-308.

Chastel, C. \& Humphery-Smith, I. (1991). Mosquito spiroplasmas. Adv Dis Vector Res 7, 149-206.

Clark, T. B. (1982). Spiroplasmas: diversity of arthropod reservoirs and host-parasite relationships. Science 217, 57-59.

Clark, T. B., Peterson, B. V., Whitcomb, R. F., Henegar, R. B., Hackett, K. J. \& Tully, J. G. (1984). Spiroplasmas in Tabanidae. Isr J Med Sci 20, 1002-1005.

Frana, M. F., Gasparich, G. E. \& Grogan, W. L., Jr (2001). First isolation of a Spiroplasma (Mollicutes: Spiroplasmataceae) from biting midges (Diptera: Ceratopogonidae). Entomol News 112, 64-70.

French, F. E., Whitcomb, R. F., Tully, J. G., Hackett, K. J., Clark, E. A., Henegar, R. B. \& Rose, D. L. (1990). Tabanid spiroplasmas of the southeastern USA: new groups and correlation with host life history strategy. Zbl Bakteriol Suppl 20, 441-444.

Gasparich, G. E., Hackett, K. J., Clark, E. A., Renaudin, J. \& Whitcomb, R. F. (1993). Occurrence of extrachromosomal deoxyribonucleic acids in spiroplasmas associated with plants, insects, and ticks. Plasmid 29, 81-93.

Hackett, K. J. (1990). Derrick Edward Award: adaptational biology and spiroplasmas. Zbl Bakteriol Suppl 20, 21-32.

Hackett, K. J. \& Clark, T. B. (1989). The ecology of spiroplasmas. In The Mycoplasmas, vol. 5, pp. 113-200. Edited by R. F. Whitcomb \& J. G. Tully. New York: Academic Press.

Hackett, K. J., Whitcomb, R. F., Clark, T. B. \& 12 other authors (1996). Spiroplasma leptinotarsae sp. nov., a mollicute uniquely adapted to its host, the Colorado potato beetle, Leptinotarsa decemlineata (Coloeoptera: Chrysomelidae). Int J Syst Bacteriol 46, 906-911.

International Committee on Systematic Bacteriology Subcommittee on the Taxonomy of Mollicutes (1995). Revised minimum standards for description of new species of the class Mollicutes (division Tenericutes). Int J Syst Bacteriol 45, 605-612.

Saglio, P., L'hospital, M., Laflèche, D., Dupont, G., Bové, J. M., Tully, J. G. \& Freundt, E. A. (1973). Spiroplasma citri gen. and sp. n.: a mycoplasma-like organism associated with "stubborn" disease of citrus. Int J Syst Bacteriol 23, 191-204.

Tully, J. G. (1983a). Cloning and filtration techniques for mycoplasmas. Methods Mycoplasmol 1, 173-177.

Tully, J. G. (1983b). Tests for digitonin sensitivity and sterol requirement. Methods Mycoplasmol 1, 355-362.

Tully, J. G. \& Whitcomb, R. F. (1991). The genus Spiroplasma. In The Prokaryotes, vol. 2, pp. 1960-1980. Edited by A. Balows, H. G. Trüper, M. Dworkin, W. Harder \& K.-H. Schleifer. New York: Springer. 
Tully, J. G., Rose, D. L., Clark, E., Carle, P., Bové, J. M., Henegar, R. B., Whitcomb, R. F., Colflesh, D. E. \& Williamson, D. L. (1987). Revised group classification of the genus Spiroplasma (class Mollicutes), with proposed new groups XII to XXIII. Int J Syst Bacteriol 37, 357-364.

Tully, J. G., Bové, J. M., Laigret, F. \& Whitcomb, R. F. (1993). Revised taxonomy of the class Mollicutes: proposed elevation of a monophyletic cluster of arthropod-associated mollicutes to ordinal rank (Entomoplasmatales ord. nov.), with provision for familial rank to separate species with nonhelical morphology (Entomoplasmataceae fam. nov.) from helical species (Spiroplasmataceae), and emended descriptions of the other order Mycoplasmatales, family Mycoplasmataceae. Int J Syst Bacteriol 43, 378-385.

Whitcomb, R. F. (1983). Culture and media for spiroplasmas. Methods Mycoplasmol 1, 147-158.

Whitcomb, R. F., Gasparich, G. E., French, F. E. \& 10 other authors (1996). Spiroplasma syrphidicola sp. nov., from a syrphid fly (Diptera: Syrphidae). Int J Syst Bacteriol 46, 797-801.

Whitcomb, R. F., French, F. E., Tully, J. G., Carle, P., Henegar, R., Hackett, K. J., Gasparich, G. E. \& Williamson, D. L. (1997).
Spiroplasma species, groups, and subgroups from North American Tabanidae. Curr Microbiol 10, 1-8.

Williamson, D. L. (1983). Specialized electron microscopic techniques for spiroplasmas in plant and insect tissues. Methods Mycoplasmol 1, 147-158.

Williamson, D. L. \& Whitcomb, R. F. (1983). Special serological tests for spiroplasma identification. Methods Mycoplasmol 2, 249-259.

Williamson, D. L., Whitcomb, R. F. \& Tully, J. G. (1978). The spiroplasma deformation test, a new serological method. Curr Microbiol 1, 203-207.

Williamson, D. L., Tully, J. G. \& Whitcomb, R. F. (1989). The genus Spiroplasma. In The Mycoplasmas, vol. 5, pp. 71-111. Edited by R. F. Whitcomb \& J. G. Tully. New York: Academic Press.

Williamson, D. L., Whitcomb, R. F., Tully, J. G. \& 10 other authors (1998). Revised group classification of the genus Spiroplasma. Int J Syst Bacteriol 48, 1-12.

Williamson, D. L., Sakaguchi, B., Hackett, K. J. \& 7 other authors (1999). Spiroplasma poulsonii sp. nov., a new species associated with male-lethality in Drosophila willistoni, a neotropical species of fruit fly. Int J Syst Bacteriol 49, 611-618. 